\title{
Potential of Urban Wetlands for Ecotourism Development- A Case of Deepor Beel, Guwahati
}

\author{
Pratiksha Baruah \\ Deptt. of Planning, School of Planning and Architecture, Vijayawada, Andhra Pradesh, India; pratikshabaruah@yahoo.com
}

Nat. Env. \& Poll. Tech. Website: www.neptjournal.com

Received: 11-08-2019

Accepted: 18-09-2019

\section{Key Words:}

Anthropogenic activities; Biodiversity; Economy;

Ecotourism;

Local community;

Wetland

\begin{abstract}
Wetlands are amongst the most productive ecosystems of the Earth. The system includes diverse features in terms of components, functions and attributes. Wetland ecosystems are essential to human well-being (Finlayson et al. 2005). A substantial body of evidence demonstrates that wetlands can deliver a great variety of benefits to human society (Ghermandi et al. 2010). Up to $87 \%$ of the global wetland resource has been lost since 1700 . The planet is losing wetlands three times faster than natural forests. Tourism is one of the significant tools to enhance and support environmental conservation. According to UNWTO, sustainable tourism means putting the principles of sustainable development, set out at the Rio Earth Summit in 1992, into practice in tourism. Deepor Beel is a permanent freshwater lake and the only Ramsar site in Assam which is experiencing adverse human activities; filling of wetlands for habitation purpose, cutting the sides of wetlands, pollution, fishing and killing of migratory birds. Degradation of water quality, sedimentation in the lake surface, deforestation activities in and around the Beel area has increased the importance of conservation and restoration of the Beel. Presently, Deepor Beel is a degrading Beel, facing threats due to urban encroachment and its illegal uses. Therefore, the research questions for this study are- (i) What are the causes and effects of deterioration of the wetland ecosystem? (ii) How to manage the wetland ecosystem through ecotourism development? The study aims to conserve urban wetlands to enhance eco-tourism and have a balanced urban development of Guwahati. To understand the potentiality of eco-tourism in Deepor Beel in Guwahati, the objectives are to understand the importance of urban wetland ecosystem and its present status, to assess the development initiatives in terms of tourism development by government and private sectors in Guwahati, to analyse the socio-economic and governance aspects of the wetland management and tourism in Guwahati and finally to suggest strategies or measures to enhance ecotourism-based wetland development. Primary and secondary data are used in the study through field study and secondary data collection from various organisations. Ecotourism opportunity spectrum is an analysis done to understand the suitability of the wetland for ecotourism development. To understand the anthropogenic impacts of human activity, water quality index, spatial pattern analysis, species diversity index, correlation analysis, carrying capacity analysis, Kuppuswamy's socio-economic scale, Karl Pearson correlation, vulnerable economic index, WTP-Demand Curve, SWOT analysis and Pralong's method is used to derive the potentiality of the wetland for ecotourism. Tools like Arc GIS, SPSS, MS Excel, Google Sketch Up and Google Earth have been used for the various analyses of the study. The study would find its application in the field of ecotourism development at the state level which would contribute to the growth of GDP to the nation. The initiatives were taken under ecotourism that incorporates policies and strategies at the organizational level, spatial planning, local community level that would also benefit the local community by generating employment as well as conserving the richness of the biodiversity of the lake. The findings and proposals of the study can be a helpful strategy to develop an appropriate policy for tourism to be beneficial to both the economic benefits of the state and empowerment of the local people.
\end{abstract}

\section{INTRODUCTION}

A wetland is a place where the land is covered by water, either salt, fresh or somewhere in between. Marshes and ponds, the edge of a lake or ocean, the delta at the mouth of a river, low-lying areas that frequently flood - all of these are wetlands. The destruction of wetlands is a concern because they are some of the most productive habitats on the planet. The Millennium Ecosystem Assessment (MEA) is a major assessment of the human impact on the environment, called for by the United Nations Secretary-General Kofi Annan in
2000, launched in 2001 and published in 2005 that popularized the term ecosystem services, the benefits gained by humans from ecosystems. Ramsar COP 11 delegates met in the morning and adopted resolutions on tourism, recreation and wetlands; wetlands and energy issues; principles for the planning and management of urban and peri-urban wetlands.

Up to $87 \%$ of the global wetland resource has been lost since 1700 . The planet is losing wetlands three times faster than natural forests. Wetland loss may be defined as "the loss of wetland area, due to conversion of wetland to non-wetland 
areas as a result of human activity" and wetland degradation is "the impairment of wetland functions as a result of human activity". About $50 \%$ of the world's wetlands have been lost in the last century, primarily through drainage for agriculture, urban development and water system regulations. According to the survey conducted by Wildlife Institute of India, 70 to 80 per cent of freshwater marshes and lakes in the Gangetic flood plains have been lost during the last 50 years. As a matter of fact, during the last century, 50 per cent of India's wetlands have been lost. The mangrove area of the country has been reduced from 7 lakh hectares in 1987 to 4.53 lakh hectares in 1995. About 32 per cent of the wetlands in India has been lost primarily through hunting and associated disturbances, 22 per cent due to human settlements, 19 per cent due to fishing and 23 per cent through drainage from agriculture. Removal of vegetation in the catchment leading to soil erosion and siltation contributes to about 15 per cent loss of wetlands. Pollution from the industries contributes to about 20 per cent loss of wetlands.

According to World Travel and Tourism Council (WTTC) tourism generates $11 \%$ of global GDP, employs 200 million people, and transports nearly 700 million international travellers per year (Eco-tourism or Eco-exploitation?, n.d.)). Of the 2,263 Ramsar Sites in the database as of March 2017, $1,660(73 \%)$ are reported to provide ecosystem services related to tourism and recreation. Ecotourism developed in India in 1970s and 1980s. Ecotourism was globally identified as a means of achieving twin goals of biodiversity conservation and sustainable development. As per World Travel and Tourism Council (WTTC), India's tourism sector ranks 7th in the world in terms of its total contribution to the country's GDP- $6.23 \%$ and $6.23 \%$ to the $8.78 \%$ of the total employment in India (2016). According to the Central Statistical Organisation (CSO) Enterprise, Ministry of Tourism, Government of India, tourism has the highest contribution to generating employment compared to different economic sectors in the country. There is a rising decadal trend in tourist visits in India, both domestic and foreign from 2006-2016.

\section{The Need of the Study}

Urbanization has turned into a reason for most environmental issues globally and therefore, has turned into a global significance. The study area, i.e. the Deepor Beel Wetland is located in Guwahati, in the state of Assam, India. The city of Guwahati is the gateway to North-Eastern India as well as an important centre for economic, social, educational, commercial and transportation activities, it has experienced rapid urban growth resulting into various environmental problems. Changing urban landscape with an increase in population growth and more demand for land is creating significant pressure on the natural land cover of Guwahati.
Deepor Beel, the lone Ramsar site in the Brahmaputra valley has been facing immense pressure in the form of drastic changes of adjoining land covers and eco-sensitive areas due to rapid urbanization in the city. The rapid growth of the city population and land cost increase has resulted in the encroachment of the Deepor Beel. Northern and eastern parts of the Beel have been occupied by the private as well as the government organizations. Encroachment problem and land-use change have changed the spatial pattern of Deepor Beel water area. Blocked natural drainage pattern and the water level imbalance in the Beel is also a cause of encroachment around the wetland. Waste disposal from industries, factories and surrounding areas are also among the major causes of degradation to the wetland. In tourism point of view, Guwahati has a high potential for tourism according to Assam Science Technology and Environment Council. Ecotourism is slowly but surely becoming a trend in the state. Guwahati endowed with splendid natural beauty, an abode of rich floral and faunal biodiversity, the treasure of plants, shrubs and herbs of medicinal value, unique ecosystems, wetlands, their grandeur and awe-inspiring beauty are the sources of perennial attraction.

\section{Research Framework}

Presently, Deepor Beel is a degrading Beel, facing threats due to urban encroachment and its illegal uses. Therefore, the research questions for this study are-

(i) What are the causes and effects of deterioration of the wetland ecosystem?

(ii) How to manage the wetland ecosystem through ecotourism development?

The basic elements of sustainable development- equity, economic sustainability and ecological sustainability represent the primary objectives of balanced urban development. Thus, the purpose of the study is to apply the elements of sustainability to the tourism industry in Guwahati. The study aims to conserve urban wetlands to enhance eco-tourism and have a balanced urban development of Guwahati.

To understand the potentiality of eco-tourism in Deepor Beel in Guwahati, the objectives are-

Objective 1: To understand the importance of urban wetland ecosystem and its present status.

Objective 2: To assess the development initiatives in terms of tourism development by government and private sectors in Guwahati.

Objective 3: To analyse the socio-economic and governance aspects of the wetland management and tourism in Guwahati. 


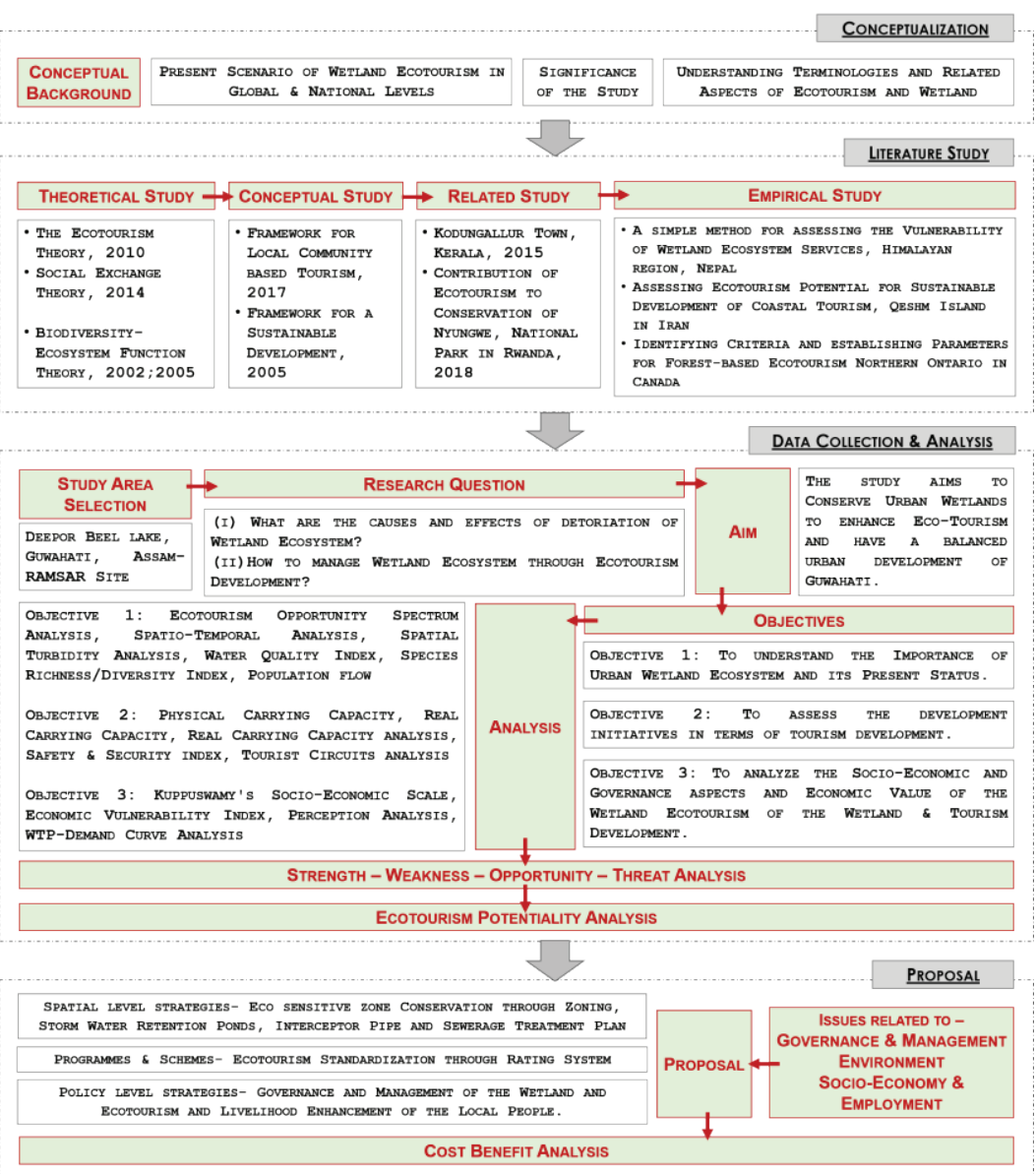

Fig. 1: Methodology.

Objective 4: To suggest strategies or measures to enhance ecotourism-based wetland development.

The methodology of the research is shown in the Fig. 1.

\section{Profile of the Study Area}

'Beel', in Assamese, means a wetland or a waterbody with diverse flora and fauna. Deepor Beel is a natural, permanent wetland, located towards the southwest of Guwahati and is considered as an important riverine wetland in the Brahmaputra valley of Assam. Deepor Beel is the only Ramsar site in Assam and among the third Ramsar site of the northeastern region of India. Deepor Beel is designated as "Wetlands of International Importance" under the Ramsar Convention on Wetlands, 1971 and was declared as Ramsar site in 2002.

The Deepor Beel lake is located about $18 \mathrm{~km}$ southwest of Guwahati city between $90^{\circ} 36^{\prime} 39^{\prime \prime} \mathrm{E}$ and $91^{\circ} 41^{\prime} 25^{\prime \prime} \mathrm{E}$ longitude and $26^{\circ} 05^{\prime} 26^{\prime \prime} \mathrm{N}$ and $26^{\circ} 9^{\prime} 26^{\prime \prime} \mathrm{N}$ latitude and 55 $\mathrm{m}$ above the mean sea level, considered as one of the largest and prominent flood-plain lakes in the Brahmaputra valley in Jalukbari Mouza of Guwahati sub-division under Kamrup (Metropolitan) district. The Beel and its adjacent villages fall under Azara revenue circle of Kamrup-metro district. The national highway 37 (NH-37) is located in the northern side of the Beel and touches its periphery at different places like Dharapur, Azara etc. The Deepor Beel falls within the jurisdiction of the Guwahati Metropolitan Development Authority within the Kamrup District, Assam. The location of the Deepor Beel has been shown in Fig. 2.

The study area has been delineated to $5 \mathrm{~km}$ buffer from the Deepor Beel lake. The study area includes a total of 18 villages within the Azara Revenue Circle under the Jalukbari Mouza- (1) Garal, (2) Mirjapur, (3) Azara, (4) Barjhar, (5) Maj-Jalukbari, (6) Gatangarh, (7) Dakshin Jalukbari, (8) Uttar Jalukbari, (9) Paschim Jalukbari, (10) Dehangarigaon, (11) Teteli, (12) Kachharigarigaon, (13) Dharapur, (14) Pub-Gaon, (15) Paschim Baragaon, (16) Kahikuchi, (17) Mikirapara Chakardai and (18) Jugipara. 


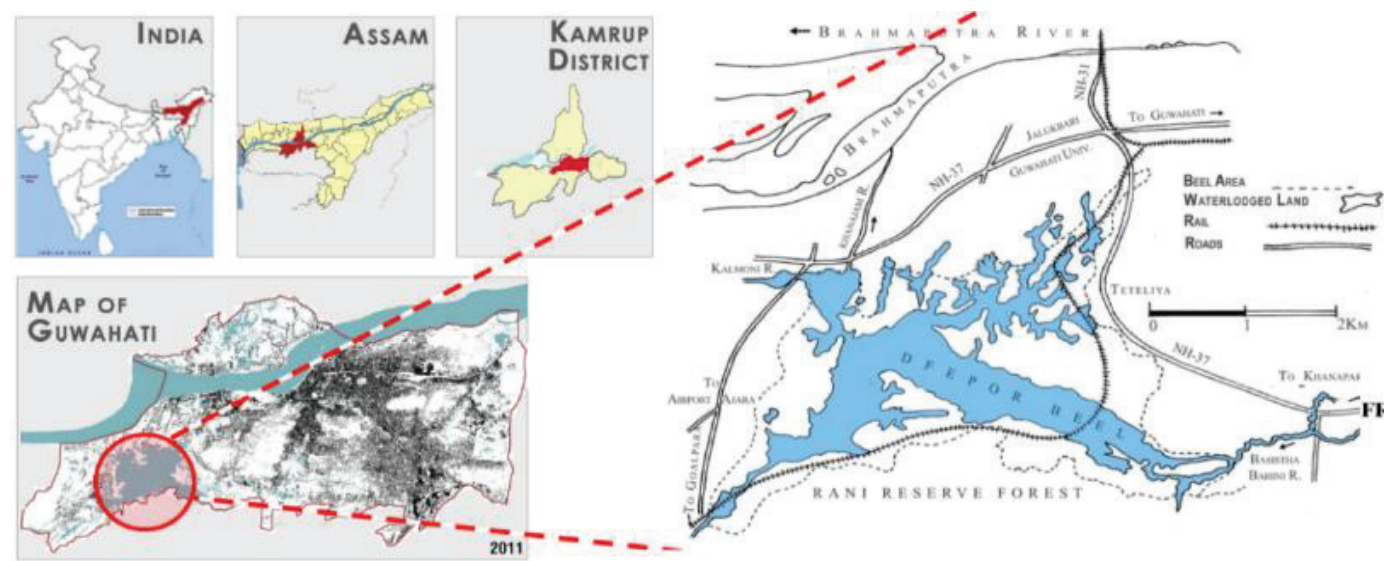

Fig. 2: Location of Deepor Beel lake.

\section{ANALYSIS}

\section{The Importance of Urban Wetland Ecosystem and its Present Status}

To understand the potential of ecotourism of the wetland, Ecotourism Opportunity Spectrum (ECOS) has been used based on past researches, experts' opinion and primary survey; of the factors - Normalized Differential Vegetation Index (NDVI), Land Surface Temperature (LST), Contour, Rarity; in terms of tourists' spots, proximity to solid waste landfill sites, proximity, proximity to modes of communication. The total ECOS score obtained is 22 in total weightage of 24 .
According to the factored points, there is a strong potentiality of tourism in the Deepor Beel wetland.

There is an increase in built-up land use within the study area which is encroaching over the wetland area causing a reduction in the wetland area as shown in Table 1 . There is a reduction in inland water (wetland area), cropland, fallow land and vegetation area due to built-up in the study area.

The calculation of the Water Quality Index (WQI) has been done using the weighted arithmetic water quality index, originally proposed by (Horton 1965) and developed by (Brown et al. 1970). Table 2 shows the location of the sampling sites.

Table 1: Change in land use.

\begin{tabular}{|llll|}
\hline & Area (sq. km.) & Change (in \%) \\
\cline { 2 - 4 } Parameters & 2008 & 2018 & $2008-2018$ \\
\hline Crop Land & 12.19 & 10.11 & 17.06 \\
Fallow Land & 10.88 & 9.19 & 15.53 \\
Inland Water & 16.92 & 11.54 & 31.79 \\
Built Up & 16.14 & 31.28 & -93.9 \\
Vegetation & 24.73 & 21.17 & 14,39 \\
\hline
\end{tabular}

Table 2: Location of the sampling sites.

\begin{tabular}{|lll|}
\hline Sampling Site & G.P.S Point & \\
\hline Site 1 & $26^{\circ} 07^{\prime} 05.2^{\prime \prime} \mathrm{N}$ & $91^{\circ} 39^{\prime} 02.8^{\prime \prime} \mathrm{E}$ \\
Site 2 & $26^{\circ} 06^{\prime} 45.2^{\prime \prime} \mathrm{N}$ & $91^{\circ} 40^{\prime} 14.5^{\prime \prime} \mathrm{E}$ \\
Site 3 & $26^{\circ} 08^{\prime} 01.1^{\prime \prime} \mathrm{N}$ & $91^{\circ} 37^{\prime} 40.1^{\prime \prime} \mathrm{E}$ \\
Site 4 & $26^{\circ} 07^{\prime} 38.9^{\prime \prime} \mathrm{N}$ & $91^{\circ} 38^{\prime} 28.1^{\prime \prime} \mathrm{E}$ \\
Site 6 & $26^{\circ} 07^{\prime} 21.9^{\prime \prime} \mathrm{N}$ & $91^{\circ} 39^{\prime} 02.8^{\prime \prime} \mathrm{E}$ \\
\hline
\end{tabular}




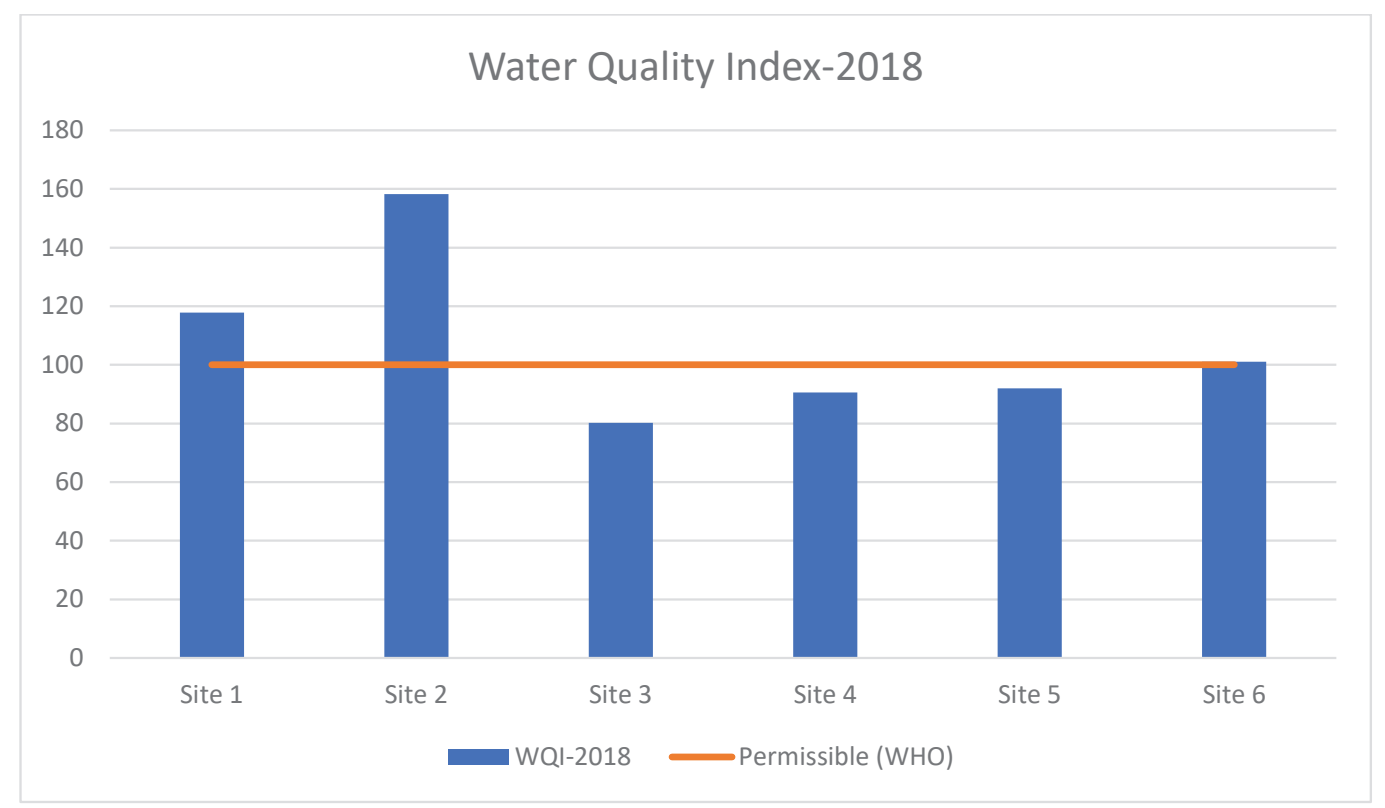

Fig. 3: Water Quality Index- 2018.

Comparing 2008 and 2018 water quality, the amount of non-satisfactory limits of parameters are temperature, total dissolved solids, turbidity and total hardness. The weighted arithmetic water quality index (WQIA) is in the following form: $W Q I A=\Sigma_{0}^{n} w i \Sigma_{0}^{n} q i$, where, $\mathrm{n}=$ the number of variables or parameters, wi $=$ relative weight of the $i^{\text {th }}$ parameter, $q i$ $=$ water quality rating of the $i^{\text {th }}$ parameter. The permissible range of Water Quality Index for Drinking Water (as per WHO, World Health Organization) is below 100 (Fig. 3).
There is a significant decrease of birds count from the year 2008 to 2018 by $47.30 \%$ of species population of above $1000-12000$ and a decrease of $39.6 \%$ of species population of above 500-900 as shown in Fig. 4 and Fig. 5 respectively.

Fish yield (in MT) has declined from 2015 to 2018 in the Deepor Beel. Fish growth rates are directly affected due to suspended matter. Increased turbidity is a form of pollution and it has consequences for nutrient supply, transport of dissolved organic materials, macrophytes, periphyton, and

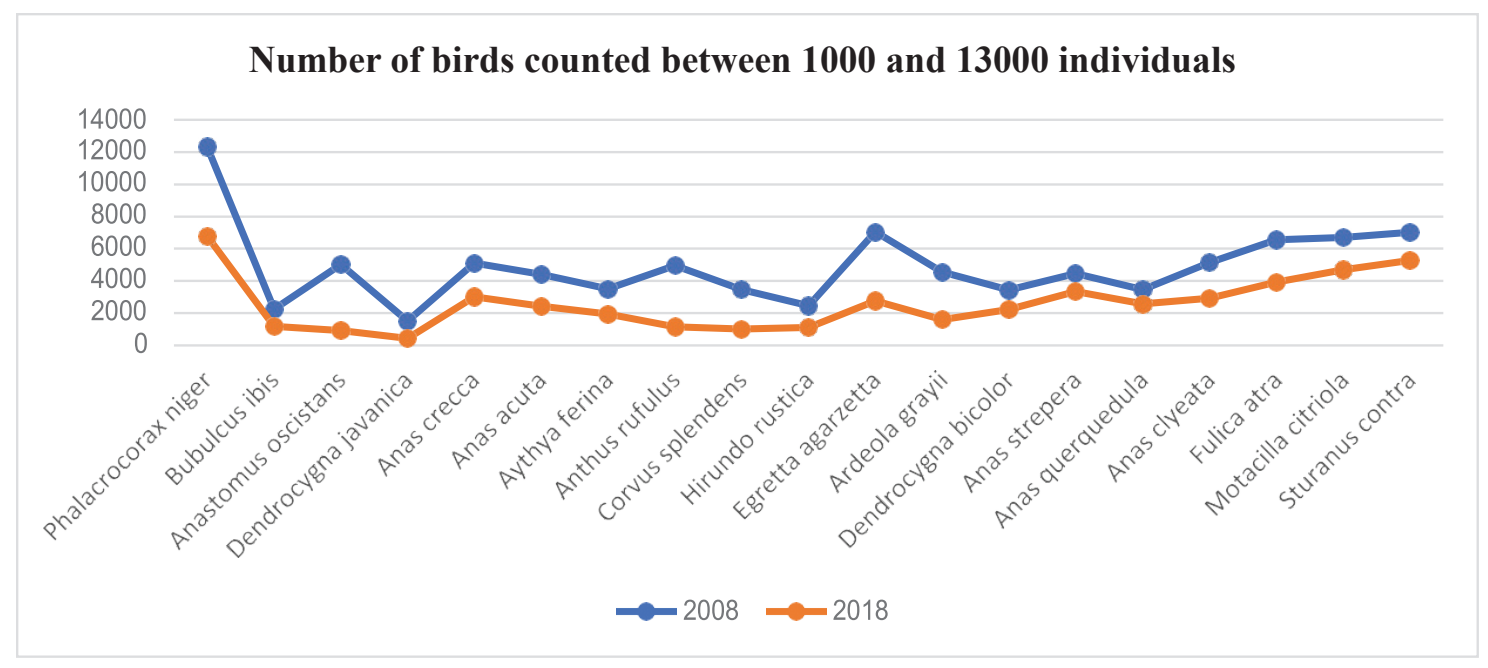

Fig. 4: Species count between 1000-13000 individuals. 


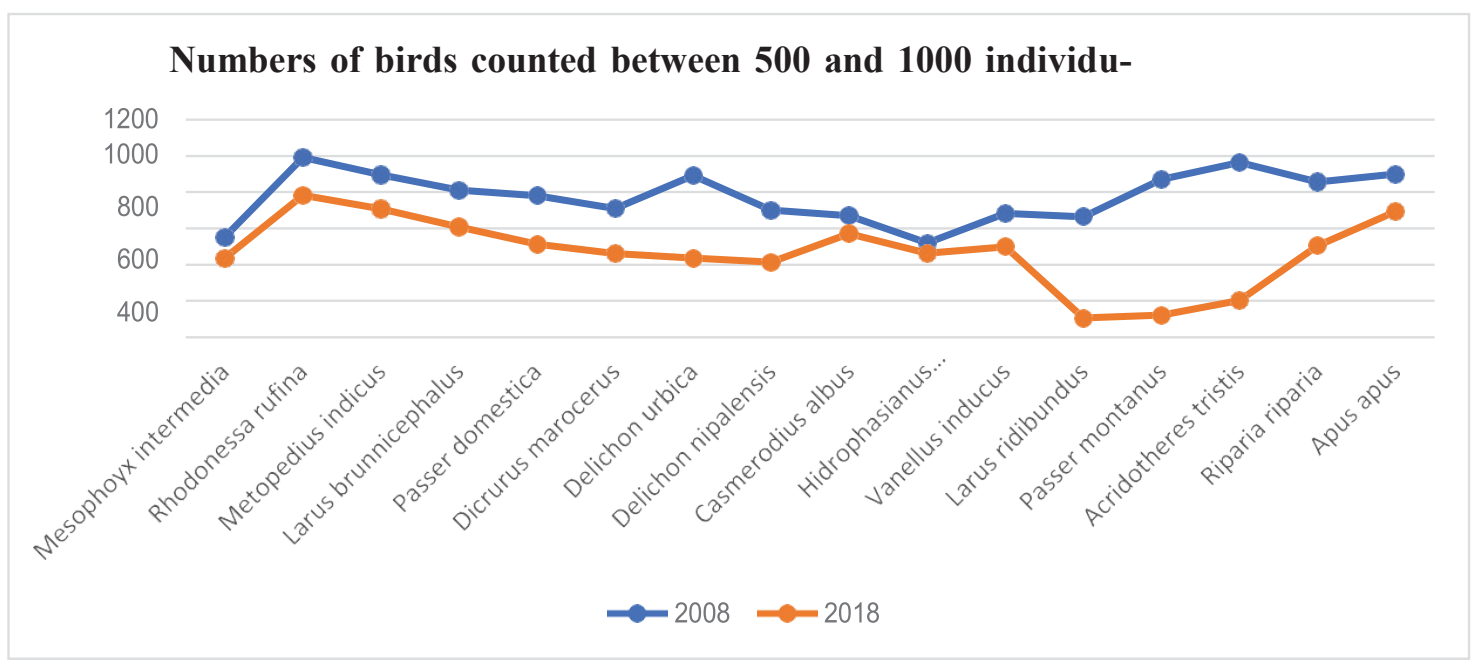

Fig. 5: Species count between 500-1000 individuals.

utilization. Applying Karl Pearson Correlation, the value of $\mathrm{R}$, Pearson's Correlation is -0.8608 . This is a strong negative correlation, which means that with increasing turbidity level, there is a decreasing fishing yield. The p-value is 0.00616 . The result is significant at $\mathrm{p}<0.05$ (Fig. 6).

The untreated wastewater was finding its way from Basistha and Dead Bharalu into Deepor Beel and was deteriorating the condition of the Beel. The original channel of Bharalu bifurcates into two rivulets- One of the rivulets known as the Basistha River flows towards Deepor Beel. Total wastewater generation is 44 MLD from the Basistha River and 25 MLD for Bharalu river. According to the State Pollution Control Board, the Bharalu and Bahini rivers pass through 11 numbers of municipal wards of the GMC area.

\section{Development Initiatives of Tourism by Government and Private Sectors in Guwahati}

Presently there are total 10 tourism agencies and operators within the city namely (1) Kamakshi Tours, (2) Sarothi Tourism, (2) Luit Tours and travels, (3) River Tours, (4) Assam on Wheels, (5) Ride \& Climb, (6) Tourism NE, (7) Barapani Boats, (8) My Voyage Tours \& Travels, (9) Zero-Valley Tourism and (10) Grand Eastern Holidays. Out of the total agencies, there are only 3 who are including Deepor Beel lake in their daily tour.

There are 5 tourism circuits in the state namely:

Circuit 1: Guwahati- Nameri- Kaziranga- Dirag-TawangTezpur- Bomdila- Guwahati;

Circuit 2: Cherrapunjee- Shillong- Mawlynong;
Circuit 3: Guwahati- Hajo- Sualkuchi- Manas- DhubriGuwahati;

Circuit 4: Dibrugarh- Saikhowa- Dehing- Patkai- Dibrugarh;

Circuit 5: Jorhat- Kaziranga- Majuli- Sivasagar- Jorhat

Out of all the tourism circuits in the state, only Circuit 3 is including the Deepor Beel lake within the tour.

Guwahati tourist spots included in the tourism circuits are categorized into pilgrimage tourism circuit, cultural tourism circuit, wildlife tourism circuit and leisure tourism circuit. The tourist spots included in the circuits are: -

Pilgrimage Circuit 1: Kamakhya temple- Umananda Temple- Basistha;

Cultural Circuit 2: NE Tribal Museum \& Cultural CentreSankardeva Kalakshetra- State Museum;

Wildlife Circuit 3: Deepor Beel lake- Amchang Wildlife Sanctuary- Nehru Park;

Leisure Circuit 4: Accoland amusement park- Northbrook Gate- Brahmaputra River cruise;

Out of all the tourism circuits in the state, only the Wildlife tourism circuit includes the Deepor Beel lake within the tour.

Current tourist inflow to the Deepor Beel Wetland (2018-19) is 305095 and 836 per day. If the tourist inflow is projected to 5 years, the projected tourist inflow according to geometric population growth calculation is 411835.17 .

Physical Carrying Capacity, $P C C-A \times V / a \times R f$; where, $\mathrm{A}=$ available area for public use; $\mathrm{V} / \mathrm{a}=$ one visitor $/ \mathrm{M} 2 ; \mathrm{Rf}$ 


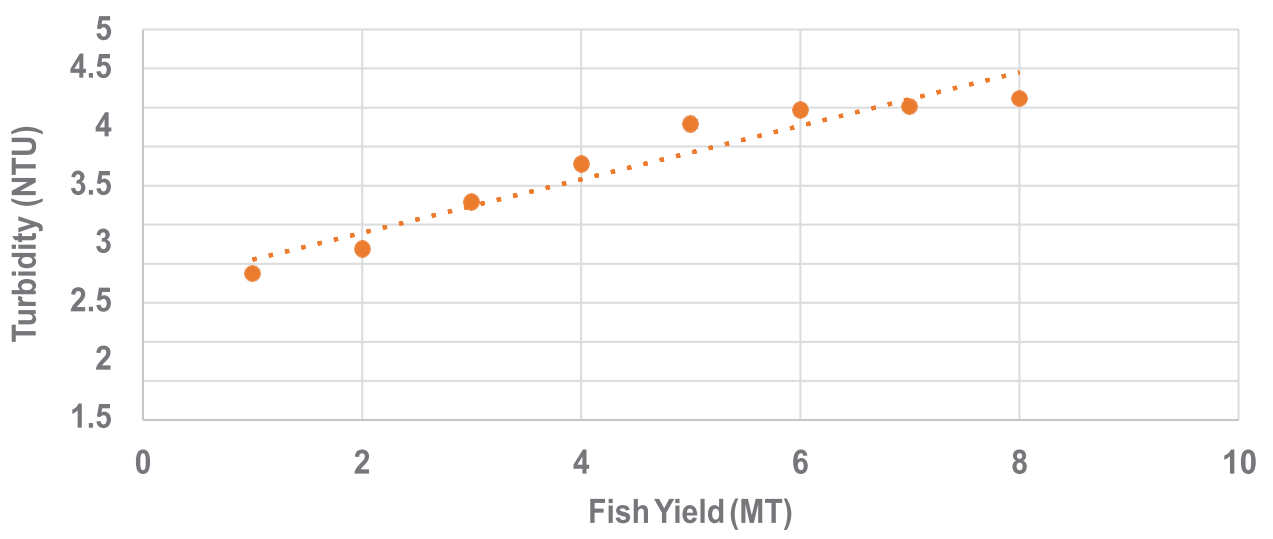

Fig. 6: Karl Pearson's coefficient.

$=$ rotation factor (number of visits per day). There can be accommodated the projected population of tourist visitors per day to the Deepor Beel lake recreational area for ecotourism at 42660 tourists per day according to the physical carrying capacity.

Real carrying capacity, $R C C-C f_{1} \times C f_{2} \ldots C f n$; where, $\mathrm{Cf}$ is a corrective factor expressed as a percentage. As the corrective factors are "site-specific", and are expressed in percentage as:

$C f-M 1 / M t \times 100 ;$ where, $\mathrm{Cf}=$ corrective factor; $\mathrm{M} 1$ $=$ limiting magnitude of the variable; $\mathrm{Mt}=$ total magnitude of the variable. Considering the corrective factors as excessive rainfall and disturbance to wildlife, there can be accommodated the projected population of tourist visitors per day to the Deepor Beel Lake Recreational Area for Ecotourism at 42463 Tourists per Day according to the Real Carrying capacity.

\section{Governance and Socio-Economic Aspects of the Wetland Management and Tourism}

The study area delineates a total of 18 villages which falls under the jurisdiction of the Guwahati Metropolitan Development Authority under the Kamrup Metropolitan District. The study area of 18 villages falls under the Azara revenue circle. There is an issue of overlapping of responsibilities at the same time lack of coordination and civic involvement in terms of the Deepor Beel lake management. There are active authorities like the Revenue Department that looks after the livelihood of the villages within the Azara Revenue circle in the study area and the Assam Forest Department who is the management authority of the Wetland.

The Assam Fisheries Department is the functional authority but is inactive because of which illegal fishing is taking place in the wetland. The Aaranyak and Eco-Concepts are the two Non-Governmental Organisations who researched the wetland in relation to conservation of biodiversity in the wetland.

Based on the socio-economic survey done on 800 households (respondents) out of 7127 households in the study area, the socio-economic status is determined using the Kuppuswamy's socioeconomic status scale, (Table 3) (Kishore et al. 2015).

Comparing self-employed weavers is $88 \%$, to weavers working under merchant is $12 \%$ and a negligible percentage of weavers working in cooperative societies. Merchants get more wages while the self-employed get lesser wages as $45.9 \%$ of weavers worked in domestic production. Weavers working under merchants got an average monthly income of Rs. 200-600, while self-employed got 600-1000. The region has more than $50 \%$ of idle looms as almost half of the weavers worked in domestic production and therefore, there is low productivity. There is a lack of commercial production due to which the share of handloom income to the total household income is below $5 \%$ while average share of handloom income to the total household income in India is $30.2 \%$.

Analytical Hierarchical Process (AHP) has been used as a tool to assess the six important parameters of ecotourism based on perception analysis as shown in Table 4. As high as $67 \%$ of the visitors were very satisfied with their experiences in visiting the wetland and about $21 \%$ were somewhat satisfied. However, $3 \%$ were not sure about the concept of ecotourism and its need. Only $1 \%$ of the visitors were very dissatisfied and $5 \%$ were quite satisfied with their experience. The major reasons for the dissatisfaction of the visitors were poor amenities and security concerns.

Willingness to pay is the Maximum Price at which the buyer would buy a good. Because the demand curve shows 
Table 3: Kuppuswamy's socioeconomic status scale.

\begin{tabular}{|c|c|c|c|}
\hline \multicolumn{2}{|c|}{ Kuppuswamy's Socio-economic Status Scale } & \multicolumn{2}{|l|}{ Class } \\
\hline \multirow{5}{*}{ Socio-Economic Class } & Upper (i) & $26-29$ & \multirow{5}{*}{ 15.65- Lower Middle } \\
\hline & Upper Middle (ii) & $21-25$ & \\
\hline & Lower Middle (iii) & $15-20$ & \\
\hline & Upper Lower (iv) & $10-15$ & \\
\hline & Lower (v) & $<10$ & \\
\hline
\end{tabular}

the maximum amount buyers are willing to pay for a given market quantity, the price given by the demand curve represents the willingness to pay of the marginal buyer. Consumer surplus is defined as the difference between the total amount that consumers are willing and able to pay for a good or service (indicated by the demand curve) and the total amount that they do pay (i.e. the market price). There is a maximum quantity demanded and consumer surplus at Rs. 50 as entry fee to the wetland as shown in Table 5.

Visitors were also asked to rate the components that need to be given importance for ecotourism development. Also, how likely the tourists are willing to use the activities/facilities if developed and their willingness to pay for the same.

\section{Ecotourism Potential Analysis}

The SWOT analysis categorizes and uses the scoring of the elements of importance applying Flavel and Williams' (Peacock, 1998) weighted quantifiable and measurable scoring methodology. The SWOT matrix is shown in Table 6.

The required data has been gathered through questionnaire and field study of the stakeholders at various levels and by applying Pralong's method, ecotourism potential of the
Deepor Beel lake is evaluated. A tourism scale (scientific, aesthetic, economic and cultural attractiveness) has been developed based on the potentiality study. Tourism Scale $=5.45$ which means there is an average potentiality of ecotourism in the Deepor Beel Lake.

\section{PROPOSALS}

The objective of the Proposal is to suggest Strategies to enhance ecotourism for wetland development. The Proposals, therefore, aims at Socio-Economic improvement, generation of Funds for the conservation of wetland and Environmental conservation in terms of policy level strategies, spatial ecotourism plan and organizational services.

\section{Socio-Economic Improvement: Introducing Co-operative Societies of Artisans}

Introducing Co-operative Societies of Artisans as an autonomous association of persons united voluntarily through a jointly owned and democratically controlled enterprise could result in socio-economic improvement in the study area. By providing 2 looms per household would provide profitability by $51 \%$ of the household income among the villages from

Table 4: AHP ranking- 6A's tourists' perception analysis.

\begin{tabular}{|c|c|c|c|c|c|}
\hline Range & Rank & & & & \\
\hline $1-12.0$ & 1 & & Very Bad & & \\
\hline $12.5-25$ & 2 & & Bad & & \\
\hline $25.5-37.0$ & 3 & & Good & & \\
\hline $37.5-50$ & 4 & & Very Good & & \\
\hline Indicator & & & & Rank & \\
\hline Attraction & & 43.2 & & 4 & Very Good \\
\hline Accessibility & & 42.5 & & 4 & Very Good \\
\hline Amenities & & 12.5 & & 2 & $\mathrm{Bad}$ \\
\hline Alertness & & 40 & & 4 & Very Good \\
\hline Accord & & 46.25 & & 4 & Very Good \\
\hline Attendance & & 30 & & 3 & Good \\
\hline
\end{tabular}


Table 5: Willingness to pay.

\begin{tabular}{|lll|}
\hline Price $(\mathrm{P})$ & Quantity Demanded (Visitors Number) & Consumer Surplus (WTP-P) \\
\hline 50 & 95 & 10805 \\
100 & 66 & 6125 \\
150 & 65 & 2675 \\
200 & 36 & -775 \\
250 & 39 & -4225 \\
300 & 18 & -7675 \\
\hline
\end{tabular}

the revenue generated per loom. Profitability from the loom is shown in Table 7.

\section{Environmental Conservation: Ecotourism Circuits}

The Deepor-Beel lake should be added with more Circuits to increase the revenue to the wetland community. The proposed Ecotourism Circuit may have the Deepor Beel Lake and it's Handloom Village added to the existing Cultural Ecotourism Circuit, Leisure Circuit and a new One Day Transit Tour. The proposed Ecotourism Circuits that includes the Deepor Beel and its Handloom Village are as shown in Table 8 and the map is as shown in Fig. 7.

\section{Environmental Conservation: Conservation Zone}

The conservation of the Deepor Beel lake is intended to bring people close to nature. Preservation of the diverse habitat of birds with the strategy to preserve the livelihood of the dependent community is the vision towards conservation proposals for Deepor Beel. The zoning has been done ensuring the conservation and preservation of the natural habitat and divided into 3 parts (Fig. 8)- the core area as ecologically protected Aquatic Eco-System, water conservation zone; A riparian corridor along the lake on all sides acts as a protective buffer and to arrest any further encroachment towards the water boundary.

Activities like eco-parks (biophilic), bird watching, forest camps, boardwalks along the forest wilderness and nature watches, picnic area, are conceived in these nature reserve areas. In the southern side, between the road and the railway line, botanical garden and children play area is proposed which will enhance the greenery of the shoreline of the lake and generate economy as well as employ some of the locals. Active recreation areas such as picnic spots and parks are proposed on the southern side of the lake. And crafts' and Fishermen village is proposed near the Beel area specially the Azara, Kahikuchi and Mirjapur. Convention Centre is proposed on the opposite side of that road. The conceptual view of the proposed eco-tourism development is as shown in Fig. 9.

The proposed riparian corridor of native trees species will further result in carbon sequestration capturing and storing atmospheric carbon dioxide. It is one method of reducing the amount of carbon dioxide. The Riparian Zone is divided into 3 zones as it is evidenced that total biomass carbon

Table 6: SWOT Matrix

\begin{tabular}{|c|c|}
\hline Strength & Weakness \\
\hline $\begin{array}{l}\text { S1: Site Suitable for Ecotourism } \\
\text { S2: Funding for Conservation \& Maintenance S3: RAMSAR Site of Inter- } \\
\text { national Importance } \\
\text { S4: Traditional Villages actively engage in Handloom Sector } \\
\text { S5: Increasing Tourists Inflow, High Carrying Capacity and Tourists actively } \\
\text { take interest in Handloom sector of local people. }\end{array}$ & $\begin{array}{l}\text { W1: Local Community lacking awareness of the importance of } \\
\text { ecotourism } \\
\text { W2: Lack of National awareness and Source of Information } \\
\text { W3: Water Contamination due to Sewerage Disposal } \\
\text { W4: Tourist Circuits not including the Wetland } \\
\text { W5: Clash of overlapping Responsibilities among the Authorities. }\end{array}$ \\
\hline Opportunity & Threat \\
\hline $\begin{array}{l}\text { O1: Masterplan 2025- GMDA focusing on Deepor Beel Wetland Tourism } \\
\text { O2: Tourists Willing to Pay for Recreation } \\
\text { O3: Local Community ready to engage in Handloom Village } \\
\text { O4: Area available for Nature-Based Development \& Afforestation } \\
\text { O5: High Fish Culture Potential }\end{array}$ & $\begin{array}{l}\text { T1: Increasing Built Up area due to Urbanization in the Eco sensitive } \\
\text { Zone } \\
\text { T2: Political Conflicts effects the Administration } \\
\text { T3: Proposed Solid Waste Landfill site within the Wetland Area in the } \\
\text { Proposed Masterplan-2025 } \\
\text { T4: Weal national perception on Ecotourism and among the various } \\
\text { Experts stakeholders } \\
\text { T5: Located in Zone V-Highest Seismic Zone in India. }\end{array}$ \\
\hline
\end{tabular}


Table 7: Profitability calculation.

\begin{tabular}{|lll|}
\hline Revenue & Unit & Amount \\
\hline Total no. of Households to be engaged & In Nos. & 82354.2 \\
Total Fixed Cost (TFC) & In Rs. & 200 \\
Total Variable Cost (TVC) & In Rs. & 1800 \\
Average Fixed Cost & In Rs. & 200 \\
Average Variable Cost & In Rs. & 900 \\
Gross Return (GR) & In Rs. & 5000 \\
Gross Margin = GR-TVC & In Rs. & 3200 \\
Gross Cost of Industry & In Rs. & 2000 \\
Net Return & In Rs. & 3000 \\
Average Return & In Rs. & 1500 \\
Per Loom Profit & In Rs. \\
Profitability & In Rs. & 4100 \\
\hline
\end{tabular}

Table 8: Ecotourism circuits.

\section{Circuits}

Circuit 1: Cultural Ecotourism Circuit

Engaging the tourists with the region's culture, specifically the lifestyle of the people in those geographical areas, the history of those people, their art, architecture, religion and elements that helped shape their way of life.

Circuit 2: Leisure Ecotourism Circuit

Providing leisure travel to tourists with an educational and adventurous experience visiting complex and fascinating ecosystems and their associated cultures and traditions.

Circuit 3: Education Ecotourism Circuit

It includes pursuing education, carrying out research activities and knowledge acquisition.

Circuit 4: One Day Transit Tour

Taking to the most important Tourism spots in the city which will increase the frequency of tourists to the sites.

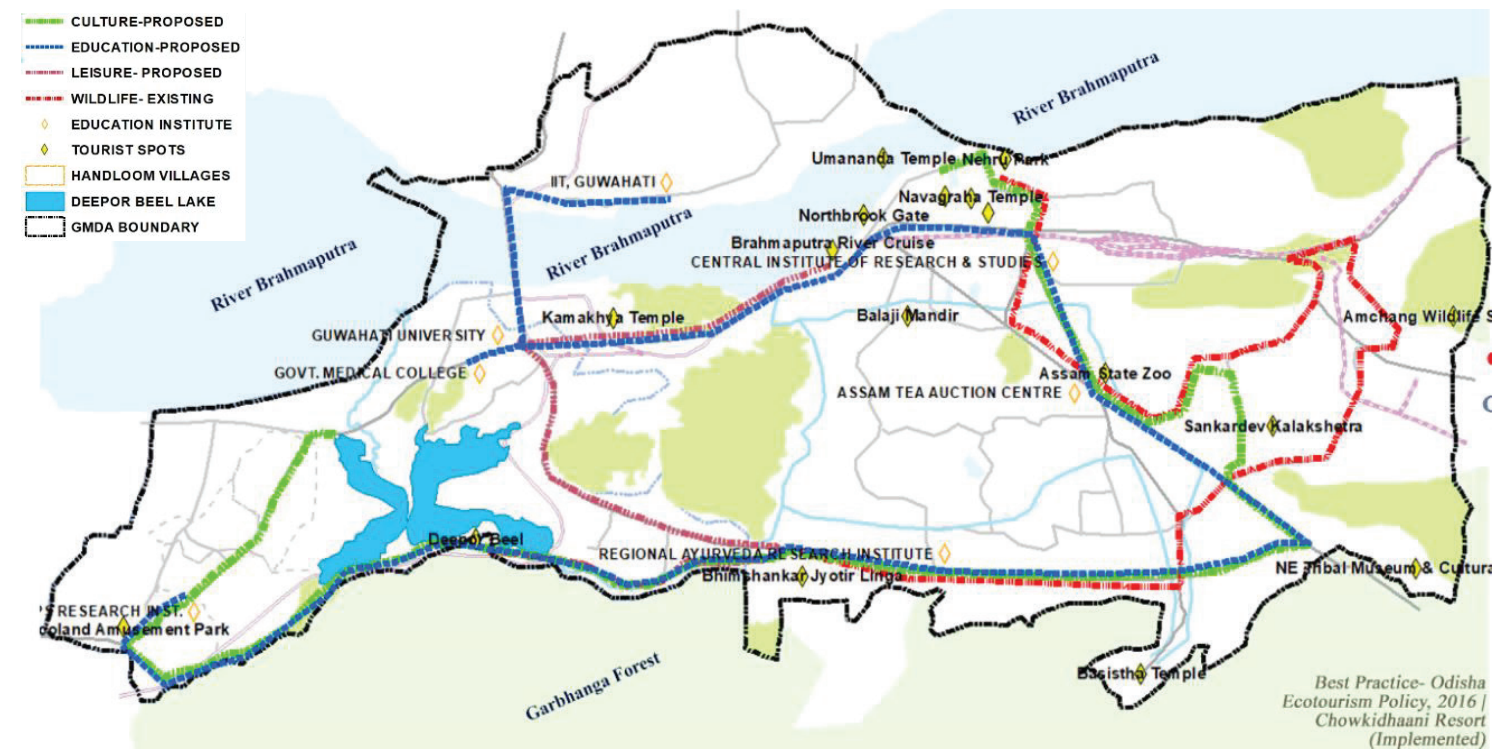

Fig. 7: Proposed tourism circuits. 


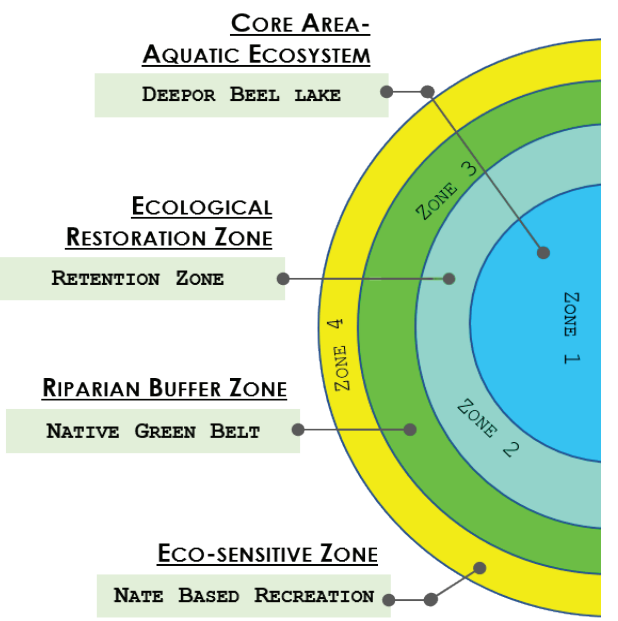

Fig. 8: Zoning of the study area.

content varies in shrubs, trees and herbs in native vegetation as shown in Fig. 10.

The amount of biomass present in the native vegetation was estimated by destructive analysis as shown in Table 9. Three native species of shrub species, herb species and tree species have been selected for biomass sampling. The biometrical parameters like height, basal diameter and root length of the uprooted plants and trees were taken.

\section{Environmental Conservation: Floating Islands}

Creating Floating Islands with indigenous Plant Species can attract more migratory and resident Water Bird Species to the Lake. Creating habitat for water birds and another aquatic biodiversity as well as improving water quality in agricultural landscapes. Due to the shrinkage of the wetland, there is a decreasing habitat for the waterbird species. These islands can act as ideal nesting grounds for animals and birds seeking safer areas as they are anchored away from the shore to help protect from predators. The map showing the potential location of the floating islands and the conceptual sketch of the floating island is as shown in Fig. 11.

\section{Environmental Conservation: Interceptor Sewerage Treatment Plant}

There is continuous damage to the Deepor Beel lake's ecosystem, due to alleged unregulated flow of sewage at the Dispur

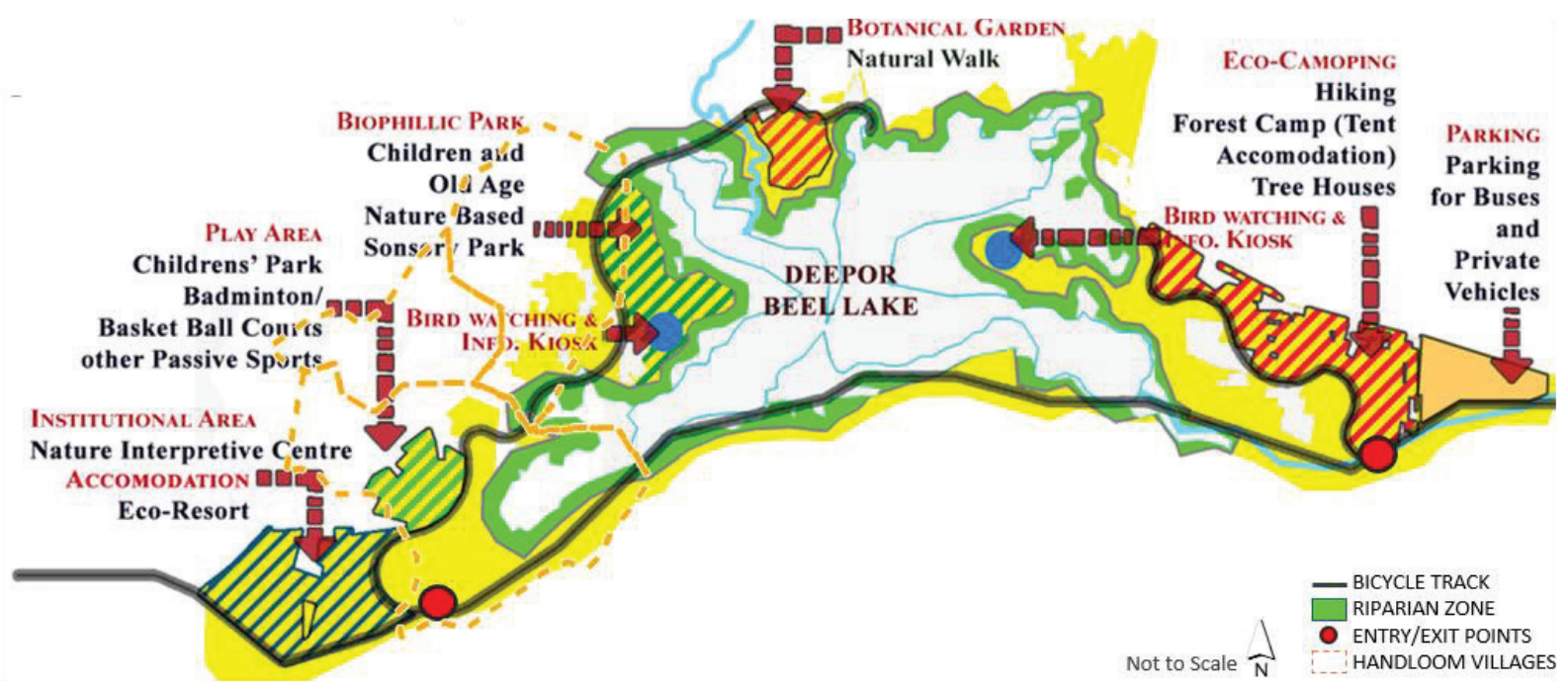

Fig. 9: Conceptual view of the proposed Ecotourism Development 
Sub-Basin which leads to deterioration of the wetlands' water quality due to seepage of such leachate through the Bharalu river. The collection of the existing sewage and stormwater drains in interceptor pipes would run parallel to the length of
Bharalu Riversides and would be conveyed to the proposed site of the 35 MLD STPs near the Deepor Beel Wetland. The estimation of the capacity of the proposed STP and the estimated cost is as shown in Table 10 and Table 11 respectively.

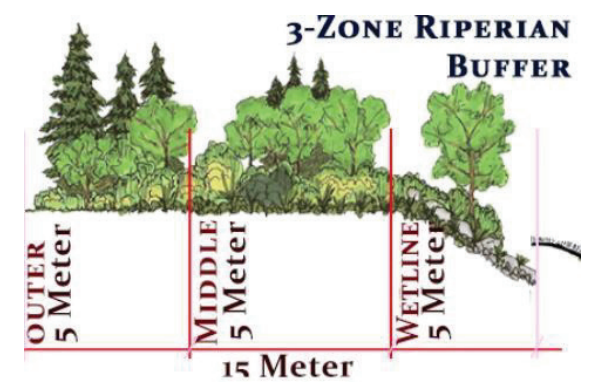

Fig. 10: Riparian buffer zoning.

Table 9: Carbon sequestration of the riparian buffer- destructive method.

\begin{tabular}{|c|c|c|c|c|c|}
\hline \multicolumn{6}{|l|}{ Details } \\
\hline Total Area of the Riparian Buffer Zone & \multirow{2}{*}{$\begin{array}{l}0.375 \text { Sq. Kms. (Area) } \\
\text { Tree }\end{array}$} & \multicolumn{4}{|c|}{ Width $=0.15 \mathrm{Kms} ;$ Perimeter $=24 \mathrm{Kms}$; No. of Zones- 3} \\
\hline \multirow[t]{3}{*}{ Native Species } & & \multicolumn{4}{|l|}{ Acacia leucophloea } \\
\hline & Shrub & \multicolumn{4}{|l|}{ Cassia auriculate } \\
\hline & Herb & \multicolumn{4}{|l|}{ Abutilon indicum } \\
\hline \multicolumn{6}{|c|}{ Calculating Biomass Carbon Storage (kg/ha)- Capacity using Destructive Method } \\
\hline Tree $=532.32$ & \multirow[t]{2}{*}{ Shrub $=487.85$} & \multicolumn{4}{|l|}{ Herb $=189.19$} \\
\hline Total Carbon Sequestration & & \multicolumn{4}{|l|}{$1209.36 \mathrm{~kg} / \mathrm{ha}$} \\
\hline \multirow[t]{2}{*}{ Carbon Storage } & & \multicolumn{4}{|l|}{$45351 \mathrm{Kg}$} \\
\hline & Leaf & Branch & Stem & Root & Total \\
\hline Acacia leophloea & 35.95 & 125.05 & 251.04 & 120.28 & 532.32 \\
\hline Cassia auriculate & 53.18 & 134.14 & 181.35 & 119.18 & 487.85 \\
\hline Abutilon indicum & 16.85 & & 44.01 & & 189.19 \\
\hline
\end{tabular}

Table 10: Estimation of STP capacity.

\begin{tabular}{|l|l|}
\hline Calculation of per Capita Sewage Generation & Demand (lpcd) \\
\hline Net per capita water demand & 135 \\
Add $10 \%$ for ICI demand @ 10\% & 13.5 \\
Add ground water infiltration @ 5\% & 6.75 \\
Sub-Total & 155 \\
Considering 80\% for sewage generation & 124 \\
Projection for Total Waste Water Generation for Bharalu Catchment Area & \\
Wards & Ward No. 24,42,43,44,45,46, 47, 48, 49,50,51,52,53,54,55,56,57,58 \\
Total Projected Population 2020 & $3,97,166$ \\
Total Projected Population 2035 & 43,073 \\
Sewerage Contribution & 125 lpcd \\
Sewage Generation 2020 & 25 \\
Sewage Generation 2035 & 33 \\
Proposed STP & 35 MLD \\
\hline
\end{tabular}


Considering the watershed of the wetland and the greater flow in the city, the location of the proposed STP is as shown in Fig. 12.

\section{Cost-Benefit Analysis}

The cost of the Project has been estimated based on the current value of the infrastructures in Guwahati (collected from Dora Beel Ecotourism Project, NGO, Assam) as shown in
Table 12. The yearly operating cost of the Project has been estimated based on GMDA estimate for Deepor Beel considering approx. cost for Site Maintenance, Running Expenses/ Utilities, Marketing \& Stationary, Wages to Permanent Employee and Misc. Expenses which has been included in the Initial Capital Cost.

Total initial investment for the Ecotourism Project has been estimated as Rs. 551.51 Lakhs. Conservation Surplus

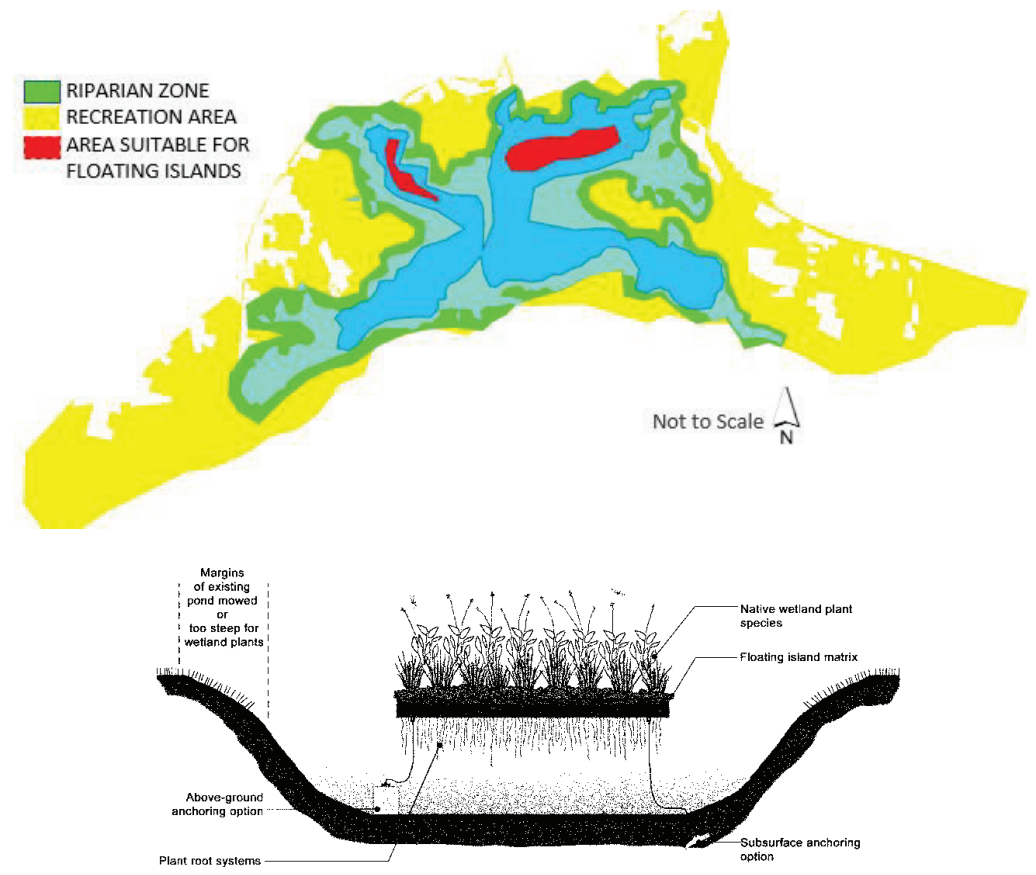

Fig. 11: Proposed floating islands

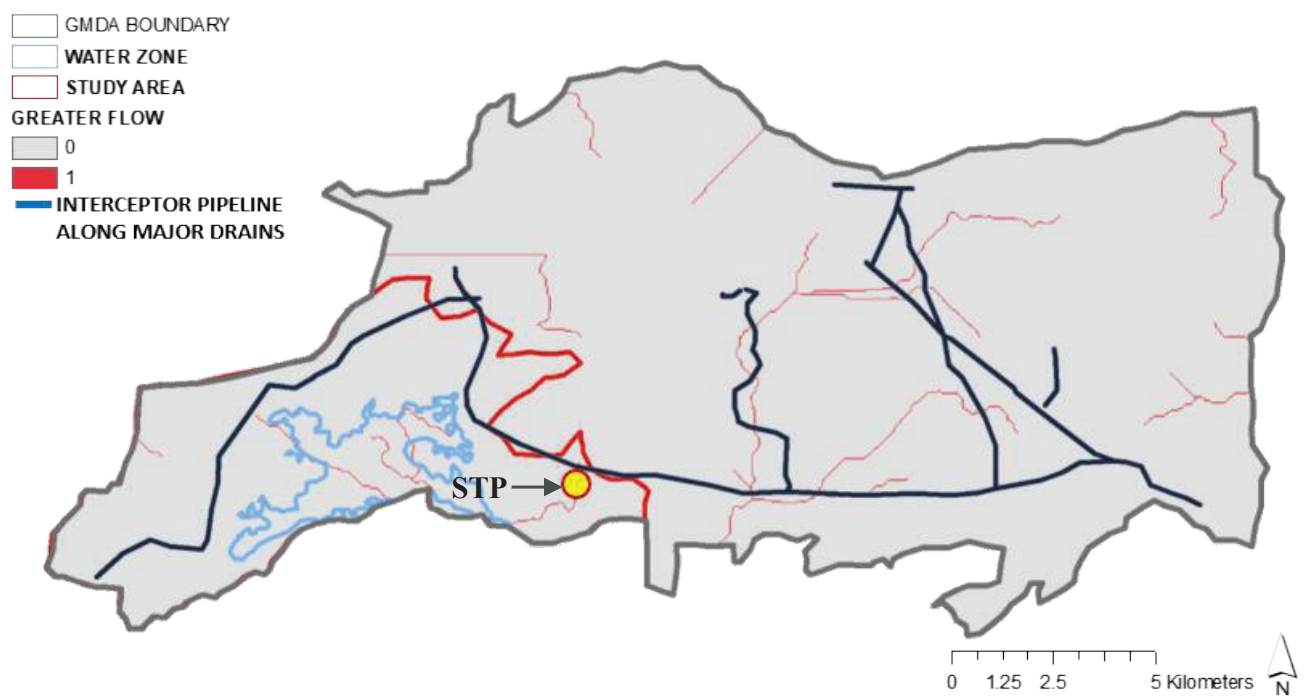

Fig. 12: Map showing the proposed Interceptor pipelines and the STP 
Table 11: Cost estimation of the proposed STP.

\begin{tabular}{|ll|}
\hline Calculation of per Capita Sewage Generation & Demand (lpcd) \\
\hline Net per capita water demand & 135 \\
Add 10\% for ICI demand @ 10\% & 13.5 \\
Add ground water infiltration @ 5\% & 6.75 \\
Sub-Total & 155 \\
Considering 80\% for sewage generation & 124 \\
Total Projected Population 2020 & $3,97,166$ \\
Total Projected Population 2035 & 43,073 \\
Sewerage Contribution & 125 lpcd \\
Sewage Generation 2020 & 25 \\
Sewage Generation 2035 & 33 \\
Proposed STP & 35 MLD \\
\hline
\end{tabular}

Table 12: Total cost.

\begin{tabular}{|l|l|}
\hline Particulars/ Activities/ Facilities & Amount (in Lakhs) \\
\hline Total Yearly Operating Cost of Project & $\mathbf{6 . 7 5}$ \\
Total Initial Capital Cost of the Project (operative expenses for 05 years) & $\mathbf{5 5 1 . 5 1}$ \\
\hline
\end{tabular}

Table 13: Total benefit.

\begin{tabular}{|lll|}
\hline & & Revenue Generated \\
\hline Benefits to Economy & Tourists visiting the Wetland-41,1835 Tourists. & Recreation- Rs. 102958750 \\
Social Benefit & $\begin{array}{l}20 \text { skilled and semi-skilled personnel with appx 12.5 L Wages per } \\
\text { annum based on Infrastructure Facilities }\end{array}$ & Rs. 6250000 \\
& Handloom Industry (Weaving) & Rs. 590400 \\
Opportunity Cost & Rs. 1097.99 Lakhs \\
\hline Total Benefit Revenue Generated & &
\end{tabular}

Rs. 540250 is the Benefit to the Environment for maintenance of the Ecosystem. The project benefits to Economy, Society and Opportunity Cost as shown in Table 13.

The calculated Cost-Benefit Ratio is 1:2.

\section{CONCLUSION}

The paper focuses on bringing out the importance of ecotourism for the conservation of urban wetland by which the wetland may contribute to the growth and development of the city. The analysis on the present status of the Deepor Beel carried out identifies issues in increasing encroachment of the wetland, deterioration of water quality and reduction in biodiversity. Further, assessment of the tourism infrastructure development establishes that there is a moderate development of physical infrastructure within the study area and that more than 30 times the projected tourists in 5 years may be accommodated in the study area with respect to physical and real carrying capacity. The governance assessment showed that there is a lack of coordination and civic involvement. The local community in the study area has a lower-middle-class socio-economic status and there is very low productivity of weaving. Analysis of the economic value of the wetland strengthens the necessity of wetland conservation through ecotourism. Based on the analysis, it is found that there is a potential of the wetland area for ecotourism. Various proposals have been established for the management of the wetland through ecotourism which would result in economic prosperity, environmental sustainability and empowerment of local communities. The cost-benefit analysis shows a ratio of 1:2 that says that the ecotourism development would add to benefit to the economy, society and environment.

\section{ACKNOWLEDGEMENT}

The publication of the research was carried out towards partial fulfilment of the requirements of the award of Master of 
Planning at the Department of Planning, School of Planning and Architecture, Vijayawada. The author wishes to thank supervisor and coordinator, Dr. Abdul Razak Mohammad, Professor, Department of Planning, for his simplified valuable guidance, motivations and encouragement.

The author also appreciates the support and cooperation received during data collection from the Guwahati Metropolitan Development Authority, Assam Pollution Control Board, Aaranyak NGO, Tourism Directorate of Assam, the local people in the villages around the Deepor Beel wetland and other authorities if missed any. The author would also like to thank the experts who were involved in the various perception analysis for the research and the participants in the survey, who have willingly shared their precious time during the process of interviewing.

\section{REFERENCES}

Brown, R. M., McClelland, N. I., Deininger, R. A. and Tozer, R. G. 1970. A water quality index-do we dare? Water Sewage Works, 117(10): 339-343.

Finlayson, M., Cruz, R.D., Davidson, N., Alder, J., Cork, S., de Groot, R.S., Lévêque, C., Milton, G.R., Peterson, G., Pritchard, D. and Ratner, B.D. 2005. Millennium Ecosystem Assessment: Ecosystems and Human Well-being: Wetlands and Water Synthesis. Island Press.

Eco-tourism or Eco-exploitation? (n.d.). Retrieved 2019, from https://sites. google.com/site/globalecotourism1/

Ghermandi, A., van den Bergh, J. C., Brander, V. M., Groot, H. L. and Nunes, P. A. 2010. Values of natural and human made wetlands: A meta analysis. Water Resources Research, 46(12).

Horton, R. 1965. An index number system for rating water quality. Journal of the Water Pollution Control Federation, 37(3): 300-306.

Kishore, J., Kohli, C. and Kumar, N. 2015. Kuppuswamy's socioeconomic scale-update for July 2015. International Journal of Preventive, Curative and Community Medicine, 26-28.

Peacock, R. Flavel, Ron and Williams, Joe 1998.Strategic Management. A Practical Approach. Small Enterprise Research, 6(1): 73-74. 